\title{
Digeneans and cestodes parasitic in the white-faced ibis Plegadis chihi (Aves: Threskiornithidae) from Argentina
}

\author{
María Celina Digiani ${ }^{1,2}$ \\ ${ }^{1}$ Departamento Científico Zoología Invertebrados, Museo de La Plata, Paseo del Bosque s/n, (1900) La Plata, Argentina; \\ ${ }^{2}$ Consejo Nacional de Investigaciones Científicas y Técnicas (CONICET)
}

Key words: Digenea, Cestoda, Plegadis chihi, Dietziella, Patagifer, Ascocotyle, Prosthogonimus, Athesmia, Posthodiplostomum, Hymenolepis, Argentina

\begin{abstract}
Some digeneans and cestodes parasitic in a population of the white-faced ibis Plegadis chihi (Vieillot) from Buenos Aires province, Argentina, are presented. The digeneans Dietziella egregia (Dietz, 1909), Patagifer bilobus (Rudolphi, 1819), Ascocotyle (Leighia) hadra Ostrowski de Núñez, 1992 and Posthodiplostomum nanum Dubois, 1937 from the intestine; Prosthogonimus ovatus (Rudolphi, 1803) from the cloaca; Athesmia heterolecithodes (Braun, 1899) from the bile ducts and the cestode Hymenolepis megalops (Nitzsch in Creplin, 1829) from the cloaca, were recorded. The discovery of $D$. egregia, $P$. ovatus, A. heterolecithodes and $P$. nanum constitute new host and/or new geographical records. Adults of $A$. (L.) hadra, previously described in experimental definitive hosts, are first reported from a naturally infected bird. Hymenolepis megalops, a cestode of Anseriformes is first reported from Ciconiiformes.
\end{abstract}

The white-faced ibis, Plegadis chihi (Vieillot, 1817) (common name in Argentina: Cuervillo de Cañada) is one of the most common Argentinean threskiornithids. It is an American species with a discontinuous distribution that ranges from Central California and the North-western USA to North-central Chile, NorthCentral Argentina and Uruguay. It is considered resident in the Neotropical portion of its range, though irregular local movements occur on a large scale throughout (Matheu and del Hoyo 1992).

This study represents the first helminthological survey for this host. Although its natural history has been well studied (see Matheu and del Hoyo 1992), parasitological data on $P$. chihi in the Northern portion of its distribution are not available. In South America, the only report was by Boero and Led (1971), who examined one specimen of $P$. chihi from Buenos Aires province, Argentina, and gave a brief description of Patagifer bilobus (Rudolphi, 1819) (Echinostomatidae), without data about intensity of infection.

During the course of a major study on the helminth parasites of aquatic birds from Buenos Aires province (Digiani 1999a), the white-faced ibis was found to harbour many helminth species. Most of them represented new host and geographical records. Three helminth species, one digenean and two nematodes, were found to be new and were subject of separate contributions (Digiani 1999a, b, 2000). Some of the described digeneans and cestodes are presented in this paper.

\section{MATERIALS AND METHODS}

Hosts were shot from April 1993 to December 1998 at the localities of Punta Blanca ( $\mathrm{n}=53)$, Guaminí $(\mathrm{n}=7)$ and Ramallo ( $\mathrm{n}=4)$, province of Buenos Aires, Argentina. The birds were dissected in the field and the viscera, frozen or preserved in $10 \%$ formalin, were transported to the laboratory for examination. The body cavity and the complete intestinal, respiratory and urogenital tract were examined for helminths.

Digeneans and cestodes were fixed under slight coverglass pressure in Bouin's fixative, AFA, or $10 \%$ formalin, stained with hydrochloric carmine and mounted in Canada balsam or in DPX mountant. Drawings were made with the aid of a camera lucida. Unless otherwise stated, measurements are given in millimetres; the range is followed by the mean in parentheses.

The helminths are deposited in the Colección Helmintológica, Museo de La Plata (CHMLP), La Plata, Argentina. For comparative purposes, the following type material from other collections was examined:

- Echinostomum egregium Dietz, 1909. Naturhistorisches Museum, Vienna, Austria (NHMW), Coll. No. 4582 [Host Geronticus coerulescens (= Theristicus coerulescens), Brazil].

- Patagifer bilobus (Rudolphi, 1819). Holotype: Museum für Naturkunde, Berlin, Germany, Coll. No. 1575 [Host Ibis falcinellus (=Plegadis falcinellus), Europe]. Paratypes: NHMW Coll. No. 4628 [Host Geronticus coerulescens (= Theristicus coerulescens), Brazil], NHMW Coll. No. 4629 [Host Ibis falcinellus (= Plegadis falcinellus), Brazil (sic)], NHMW Coll. No. 4631 [Host Tantalus falcinellus (= Plegadis falcinellus), Europe] and NHMW Coll. No. 4633 (Host Platalea leucorodia, Europe).

- Patagifer consimilis Dietz, 1909. NHMW Coll. No. 4634 [Host Geronticus albicollis (= Theristicus caudatus), Brazil]. 


\section{RESULTS}

\section{DIGENEA}

Dietziella egregia (Dietz, 1909) Skrjabin et Bashkirova, 1956 Figs. 1, 4, Table 1

$\mathrm{S}$ it e of in fection: Intestine.

L o c a 1 i t y : Punta Blanca, province of Buenos Aires, Argentina.

Prevalen ce : $46.7 \%$

In te n s ity of infection:2-10,722 (mean=823.5) per infected host.

M a t e ri a 1 s t u di e d : 62 whole-mounts, 29 measured.

Comments: New host and new geographical record. This species was originally described as Echinostomum egregium Dietz, 1909, parasitic on the Brazilian threskiornithid Geronticus coerulescens (=Theristicus coerulescens) (Dietz 1909). Since its description, the species has not been mentioned from other hosts and/or localities. The specimens studied, although slightly smaller in size (Table 1), closely conform to the description by Dietz (1910). Moreover, the examination of an unstained paratype of E. egregium (NHMW Coll. No. 4582) failed to reveal any differences with specimens obtained from $P$. chihi.

The genus Dietziella Skrjabin et Bashkirova, 1956 was created to accommodate three species of avian echinostomes formerly included in the genus Echinostomum, namely: E. deparcum, Dietz, 1909, E. egregium Dietz, 1909 (the specific name becoming egregia) and E. volvulus Odhner, 1911. Both E. deparcum and $E$. egregium had been previously regarded as species inquirendae by Dietz (1909, 1910), as they were not clearly assignable to any existing genera of Echinostomatidae. Representatives of Dietziella are characterised by a single, uninterrupted row of cephalic spines; a rather long oesophagus; ventral sucker markedly larger than oral sucker, positioned a little closer to midbody than to anterior extremity; cirrus pouch weakly developed; weakly developed vitellaria in posterior half of body and uterus short, with a low number of large eggs (Yamaguti 1971). Yamaguti (1971) recognised Dietziella as a valid genus and agreed with the allocation to the genus of the above mentioned species. The validity of Dietziella is here accepted as Yamaguti (1971) did. However, the specific name Echinostoma egregium Dietz was kept in some posterior, even recent publications, for this Brazilian species (Travassos et al. 1969, Thatcher 1993). There is still some confusion as to the definition of the genus Echinostoma (Huffman and Fried 1990), but there is general agreement that members of this genus have, among other generalised features, a body size ranging from 4 to $20 \mathrm{~mm}$, suckers in the anterior third of body, a short oesophagus, and a high number (may be thousands) of eggs in utero (Huffman and Fried 1990). In view of the necessity to clearly define genera and species in the family Echinostomatidae (Huffman and Fried 1990, Kanev 1985, 1994), the position of Brazilian authors appears inconsistent, and it seems inappropriate to retain this species within the genus Echinostoma, as it is presently defined. Even so, lifehistory studies are being conducted on D. egregia in Buenos Aires province, which may help to clarify its generic position. The scarce records and the narrow host range reported hitherto for $D$. egregia suggest a strong host specificity of this species for threskiornithids.

\section{Patagifer bilobus (Rudolphi, 1819) Dietz, 1909}

Figs. 2, 5, Table 2

Site of infection: Intestine.

L o c a 1 i t i e s : Punta Blanca, Ramallo and Guaminí, province of Buenos Aires, Argentina.

Preva 1 e n c e : $83.6 \%$.

I n t e n s i t y of infection : 1-95 (mean $=14.8)$ per infected host.

M a te ri a 1 s t ud i e d : 56 whole-mounts, 28 measured.

Comments: $P$. bilobus, the type-species of the genus, originally described from the European glossy ibis Plegadis falcinellus, has also been reported from other threskiornithids from Europe and South America (Dietz 1909, 1910, Yamaguti 1971, Onda et al. 1983). Most characters of the specimens from Plegadis chihi agreed with previous descriptions of $P$. bilobus; however, no certain reference to the relative size and arrangement of corner spines was provided in those descriptions. Data from the literature and the material examined revealed that the number, size, arrangement and asymmetry of cephalic spines, especially corner spines (Lumsden 1962, Richard 1964), is one of the more reliable characters to differentiate species in the genus. Other characters usually show a great individual variation (Lumsden 1962, Jain and Srivastava 1970). Examination of types of $P$. bilobus from several European and Brazilian hosts showed consistently identical arrangement and asymmetry of corner spines of the specimens from $P$. chihi and the paratypes from four South American and European hosts. That is, of the two pairs (oral and aboral) of corner spines, the outer spine of the oral pair appears always markedly narrower than the inner of the same pair, whereas both spines of the aboral pair are of similar width (Fig. 4, Table 2). The same asymmetry was also observed by Ostrowski de Núñez (pers. comm.) in the holotype of $P$. bilobus stored in the Berlin Museum.

In view of the consistent similarity of the spines, and since no significative differences were observed in other morphological and morphometrical characters (Table 2), specimens from $P$. chihi should be assigned to $P$. bilobus. However, considering the host and geographical range of Patagifer species, it is found that nine of eleven valid species described hitherto are parasitic on Threskiornithidae (Lumsden 1962, Jain and Srivastava 1970, Onda et al. 1983). As showed by Onda 

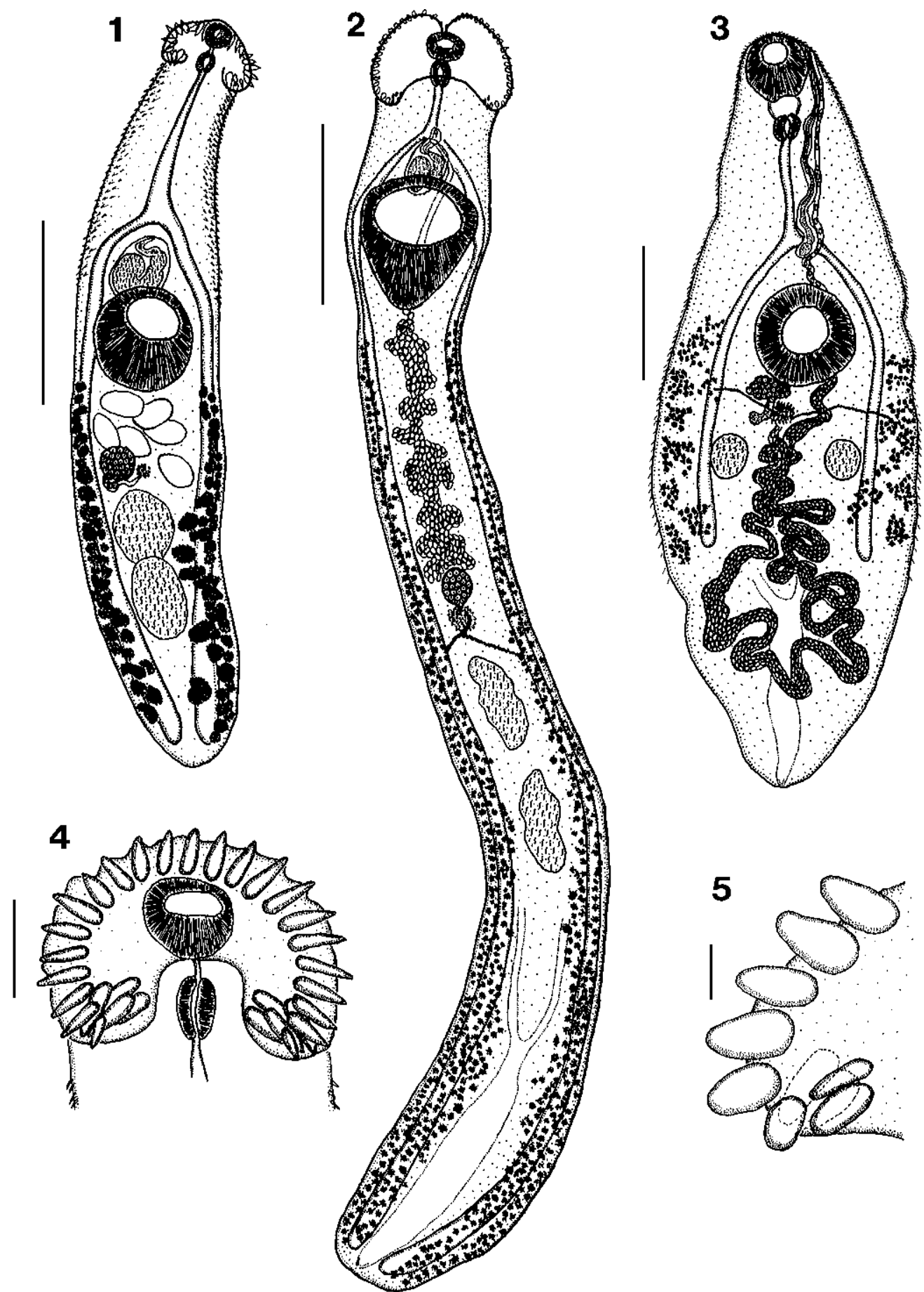

Figs. 1-5. Digeneans and cestodes parasitic in Plegadis chihi. Fig. 1. Dietziella egregia, ventral view. Fig. 2. Patagifer bilobus, ventral view. Fig. 3. Prosthogonimus ovatus, ventral view. Fig. 4. Dietziella egregia, detail of peristomic disk. Fig. 5. Patagifer bilobus, detail of right corner spines, aboral pair in dotted lines. Scale bars: Figs. $1,3=0.5 \mathrm{~mm}$; Fig. $2=2 \mathrm{~mm}$; Figs. 4,5 $=0.1 \mathrm{~mm}$. 
Table 1. Comparative measurements of Dietziella egregia.

\begin{tabular}{|c|c|c|c|}
\hline & & Dietz (1910) & Present study \\
\hline \multicolumn{2}{|l|}{$\mathrm{N}$} & 3 & 29 \\
\hline \multicolumn{2}{|l|}{ Body length } & $1.61-1.98$ & $1.01-2.09(1.58)$ \\
\hline \multicolumn{2}{|l|}{ Body width } & $0.34-0.42$ & $0.21-0.37(0.28)$ \\
\hline \multicolumn{2}{|l|}{ Peristomic disk } & $0.31-0.33$ & $0.161-0.256(0.198)$ \\
\hline \multicolumn{2}{|l|}{ No. of spines } & $31(4-23-4)$ & $31(4-23-4)$ \\
\hline \multicolumn{2}{|l|}{ Corner spines } & $62.4-74.4 \times 16.8-19.2 \mu \mathrm{m}$ & $42-55(49.5) \times 9-15(12.7) \mu \mathrm{m}$ \\
\hline \multicolumn{2}{|l|}{ First dorsal spine } & $36-38.4 \times 9-9.6 \mu \mathrm{m}$ & $21-30(24.2) \times 7.5-12(6.6) \mu \mathrm{m}$ \\
\hline \multicolumn{2}{|l|}{ Dorsal spines } & $48-61.2 \times 12-14.4 \mu \mathrm{m}$ & $36-53(44.9) \times 9-12(10.4) \mu \mathrm{m}$ \\
\hline Oral sucker & $\begin{array}{l}\text { length } \\
\text { width }\end{array}$ & $0.068-0.077 \varnothing$ & $\begin{array}{l}0.034-0.071(0.054) \\
0.038-0.073(0.054)\end{array}$ \\
\hline \multirow{2}{*}{$\begin{array}{l}\text { Prepharynx } \\
\text { Pharynx }\end{array}$} & & $0.029-0.034$ & $0.007-0.057(0.031)$ \\
\hline & $\begin{array}{l}\text { length } \\
\text { width }\end{array}$ & 0.060-0.067 Ø & $\begin{array}{l}0.041-0.073(0.049) \\
0.018-0.044(0.035)\end{array}$ \\
\hline \multicolumn{2}{|l|}{ Oesophagus } & $0.34-0.40$ & $0.165-0.379(0.256)$ \\
\hline Ventral sucker & $\begin{array}{l}\text { length } \\
\text { width }\end{array}$ & $0.23-0.25 \varnothing$ & $\begin{array}{l}0.165-0.249(0.211) \\
0.156-0.248(0.192)\end{array}$ \\
\hline Anterior testis & $\begin{array}{l}\text { length } \\
\text { width }\end{array}$ & $\begin{array}{l}0.20-0.24 \\
0.15-0.17\end{array}$ & $\begin{array}{l}0.087-0.194(0.139) \\
0.086-0.195(0.120)\end{array}$ \\
\hline Posterior testis & $\begin{array}{l}\text { length } \\
\text { width }\end{array}$ & $\begin{array}{l}0.23-0.27 \\
0.15-0.16\end{array}$ & $\begin{array}{l}0.124-0.296(0.185) \\
0.072-0.200(0.111)\end{array}$ \\
\hline Ovary & $\begin{array}{l}\text { length } \\
\text { width }\end{array}$ & $0.075-0.089 \varnothing$ & $\begin{array}{l}0.052-0.138(0.094) \\
0.055-0.142(0.077)\end{array}$ \\
\hline Cirrus pouch & $\begin{array}{l}\text { length } \\
\text { width }\end{array}$ & not given & $\begin{array}{l}0.101-0.285(0.126) \\
0.062-0.209(0.090)\end{array}$ \\
\hline \multicolumn{2}{|c|}{$\begin{array}{l}\text { Eggs } \\
\text { No. of eggs in utero }\end{array}$} & $\begin{array}{c}96-100 \times 58-60 \mu \mathrm{m} \\
6-10\end{array}$ & $\begin{array}{c}90-135 \times 46-87 \mu \mathrm{m} \\
1-10\end{array}$ \\
\hline
\end{tabular}

Table 2. Comparative measurements of examined Patagifer bilobus. Non-gravid specimens from Platalea leucorodia (NHMW paratypes) not included.

\begin{tabular}{|c|c|c|c|c|c|}
\hline \multicolumn{2}{|c|}{ Host } & $\begin{array}{l}\text { T. coerulescens } \\
\text { (paratypes) }\end{array}$ & $\begin{array}{l}\text { "P. falcinellus" } \\
\text { (paratypes) }\end{array}$ & $\begin{array}{l}\text { P. falcinellus } \\
\text { (paratypes) }\end{array}$ & $\begin{array}{c}\text { P. chihi } \\
\text { (present study) }\end{array}$ \\
\hline \multicolumn{2}{|c|}{ Provenance } & Brazil & Brazil (sic) & Europe & Argentina \\
\hline \multicolumn{2}{|l|}{$\mathrm{N}$} & 2 & 2 & 6 & 28 \\
\hline \multicolumn{2}{|l|}{ Body length } & $10.54-12.85$ & $5.13-11.71$ & $5.30-8.94$ & $10.08-20.06(14.16)$ \\
\hline \multicolumn{2}{|l|}{ Body width } & $1.14-1.79$ & $0.798-1.28$ & $0.88-1.53$ & $1.17-1.99(1.60)$ \\
\hline \multicolumn{2}{|l|}{ Peristomic disk } & $0.855-1.596$ & $0.474-1.14$ & $0.570-1.225$ & $1.152-2.037(1.545)$ \\
\hline \multirow[t]{2}{*}{ Oral sucker } & length & 0.435 & $0.174-0.329$ & $0.174-0.367$ & $0.247-0.432(0.346)$ \\
\hline & width & 0.338 & $0.155-0.329$ & $0.174-0.367$ & $0.297-0.528(0.407)$ \\
\hline \multirow[t]{2}{*}{ Ventral sucker } & length & $1.14-1.71$ & $0.684-1.197$ & $0.855-1.254$ & $1.104-2.064(1.562)$ \\
\hline & width & $0.997-1.368$ & $0.541-0.997$ & $0.627-1.054$ & $0.912-1.680(1.286)$ \\
\hline \multirow{2}{*}{ Pharynx } & length & $0.300-0.338$ & $0.140-0.242$ & $0.159-0.280$ & $0.240-0.393(0.315)$ \\
\hline & width & $0.222-0.309$ & $0.121-0.184$ & $0.149-0.222$ & $0.153-0.278(0.224)$ \\
\hline \multirow{2}{*}{ Anterior testis } & length & $0.793-0.822$ & 0.774 & $0.803-0.967$ & $0.739-1.478(1.096)$ \\
\hline & width & $0.309-0.406$ & 0.358 & $0.406-0.464$ & $0.259-0.679(0.412)$ \\
\hline \multirow[t]{2}{*}{ Posterior testis } & length & 0.687 & 0.803 & $0.841-0.919$ & $0.806-1.703(1.167)$ \\
\hline & width & 0.406 & 0.377 & $0.367-0.396$ & $0.268-0.679(0.412)$ \\
\hline \multirow[t]{2}{*}{ Cirrus pouch } & length & & & $0.387-0.629$ & $0.451-0.816(0.668)$ \\
\hline & width & not measured & not measured & $0.319-0.483$ & $0.211-0.518(0.416)$ \\
\hline \multirow[t]{2}{*}{ Ovary } & length & 0.435 & 0.348 & 0.406 & $0.336-0.679(0.480)$ \\
\hline & width & 0.300 & 0.300 & 0.483 & $0.201-0.548(0.376)$ \\
\hline \multirow[t]{2}{*}{ Eggs } & length & $0.087-0.101$ & $0.084-0.089$ & $0.084-0.092$ & $0.094-0.125$ \\
\hline & width & $0.053-0.055$ & $0.051-0.055$ & $0.051-0.055$ & $0.054-0.075$ \\
\hline \multicolumn{2}{|c|}{$\begin{array}{l}\text { No. of marginal spines on each } \\
\text { lobe }\end{array}$} & $25-26$ & 22 & $22-24$ & $21-24$ \\
\hline \multicolumn{2}{|c|}{ Inner oral corner spine (in $\mu \mathrm{m}$ ) } & not measured & $52-74 \times 13-46$ & $58-86 \times 23-27$ & $80-120 \times 32-60$ \\
\hline \multicolumn{2}{|c|}{ Outer oral corner spine (in $\mu \mathrm{m}$ ) } & not measured & $44-60 \times 11-18$ & $51-83 \times 16-22$ & $70-123 \times 22-38$ \\
\hline \multicolumn{2}{|c|}{ Inner aboral corner spine (in $\mu \mathrm{m}$ ) } & not measured & $57-74 \times 16-31$ & $64-80 \times 23-27$ & $78-145 \times 29-52$ \\
\hline \multicolumn{2}{|c|}{ Outer aboral corner spine (in $\mu \mathrm{m}$ ) } & not measured & $56-84 \times 17-22$ & $53-86 \times 21-26$ & $74-147 \times 28-50$ \\
\hline
\end{tabular}


et al. (1983), most species in the genus have a rather restricted geographical distribution and host range, which may suggest a relatively high degree of host specificity between parasites of the genus Patagifer and hosts of the family Threskiornithidae. Regarding this, all the reports of $P$. bilobus from different hosts and regions could be regarded with suspicion, in spite of the morphological similarity.

The probable existence of several species in this "bilobus-group" from different hosts was suggested by Dietz (1910). The presence of at least two species morphologically distinct from the "bilobus-type" in South and North America (P. consimilis Dietz, 1909 in Theristicus spp. and P. vioscai Lumsden, 1962 in Eudocimus albus, respectively) indicate that speciation in the genus Patagifer is relatively ancient and has occurred in American threskiornithids. The possibility exists that in some cases, speciation in Patagifer resulted in species differing not at morphological but at molecular or biological level. Life-history and/or molecular studies should be carried out on the parasites from different localities in order to confirm or to rule out differences at such level.

Previous reports of Patagifer species from Argentinean birds are those of Boero and Led (1971) of $P$. bilobus from Plegadis chihi, and Boero and Led (1968) of P. consimilis from Theristicus caudatus melanopis (=T. melanopis) from the La Plata Zoological Garden.

\section{Prosthogonimus ovatus (Rudolphi, 1803)}

Fig. 3

Site of infection: Cloaca.

L o c a 1 i t y : Punta Blanca, province of Buenos Aires, Argentina.

Prevalence $: 3.5 \%$.

Intensity of infection: 1-18 (mean=9.5) per infected host.

M a t e ri a 1 s t u d i e d : 8 whole-mounts, all measured.

Comments: New host record. Prosthogonimus ovatus is a ubiquitous species with a high degree of intraspecific variability and rather low host specificity (see Kohn and Fernandes 1972). Measurements of the present material fit the range of variability stated for this species by these authors, who examined all the Prosthogonimus species recovered from Brazilian birds (17 families and 9 orders), and concluded that all of them should be considered as variations of $P$. ovatus. Travassos $(1922,1928)$ had made the same conclusion. The species was previously recorded in Argentina as $P$. cuneatus (Rudolphi, 1803) from Gallus gallus dom. (Wolffhügel 1909). In the study area it was observed in the autochthonous birds Furnarius rufus (Furnariidae) (Digiani 1999a), and Nothura maculosa and Rynchotus rufescens (Tinamidae) (C. Mordeglia, Fac. Cienc. Nat. Mus., La Plata, Argentina; pers. comm.).
Ascocotyle (Leighia) hadra Ostrowski de Núñez, 1992 Figs. 6, 9, Table 3

$\mathrm{S}$ it e of in fection: Intestine.

L o c a 1 i t y : Punta Blanca, province of Buenos Aires, Argentina.

Prevalence : $17.7 \%$.

In te n s ity of infection: 1-1,483 (mean=354) per infected host.

M a t e r i a 1 s t u di e d: 92 whole-mounts, 20 measured.

Comments: New host record. This species was described by Ostrowski de Núñez (1992), who obtained the adults experimentally from cercariae emerging from naturally infected Littoridina parchappei (Hydrobiidae), which formed metacercariae in the fishes Jenynsia lineata (Jenynsidae) and Cnesterodon decenmaculatus (Poeciliidae). Ostrowski de Núñez (1992) distinguished the species from the type species Ascocotyle (Leighia) mcintoshi Price, 1936, by behavioural and morphological differences of cercarial, metacercarial and adult stages. Some piscivorous birds that were common in the study area were suspected as natural hosts of this species (Ostrowski de Núñez 1992).

Specimens obtained from $P$. chihi closely conform to the description by Ostrowski de Núñez (1992), i.e. they showed identical number of gonotyl folds and vitelline follicles and identical number and size of oral spines to those obtained experimentally, as well as comparable measurements of pharynx, ventral sucker and eggs. Minor differences were found in body and gonadal sizes, the specimens from $P$. chihi being slightly smaller than those obtained experimentally (Table 3).

Plegadis chihi is the first natural final host recorded for this species. Threskiornithids seem to be common hosts for species of the subgenus Leighia. Other species in the subgenus reported from this group are all from Florida state, USA: A. mcintoshi in Eudocimus albus (Bush and Forrester 1976) and Ajaia ajaja (=Platalea ajaja) (Sepúlveda et al. 1994), and A. chandleri Lumsden, 1963 in A. ajaja (=P. ajaja) (Sepúlveda et al. 1994).

Previous reports of Ascocotyle species from Argentinean birds are as follows:

- Ascocotyle sp. from Ajaia ajaja (=Platalea ajaja) at the La Plata Zoological Garden (Boero and Led 1968). The distribution of vitellaria of the figured specimen seems to correspond to the subgenus Phagicola Faust, 1920 , but the lack of oral spines precludes specific identification.

- Ascocotyle filippei Travassos, 1928 from Spheniscus magellanicus (Boero et al. 1972a).

- Ascocotyle (A.) tenuicollis Price, 1935 from naturally infected Nycticorax nycticorax (Ostrowski de Núñez 1974), Butorides striatus and Ixobrychus involucris (Ostrowski de Núñez 1976). Also obtained experimentally by Ostrowski de Núñez (1974). 

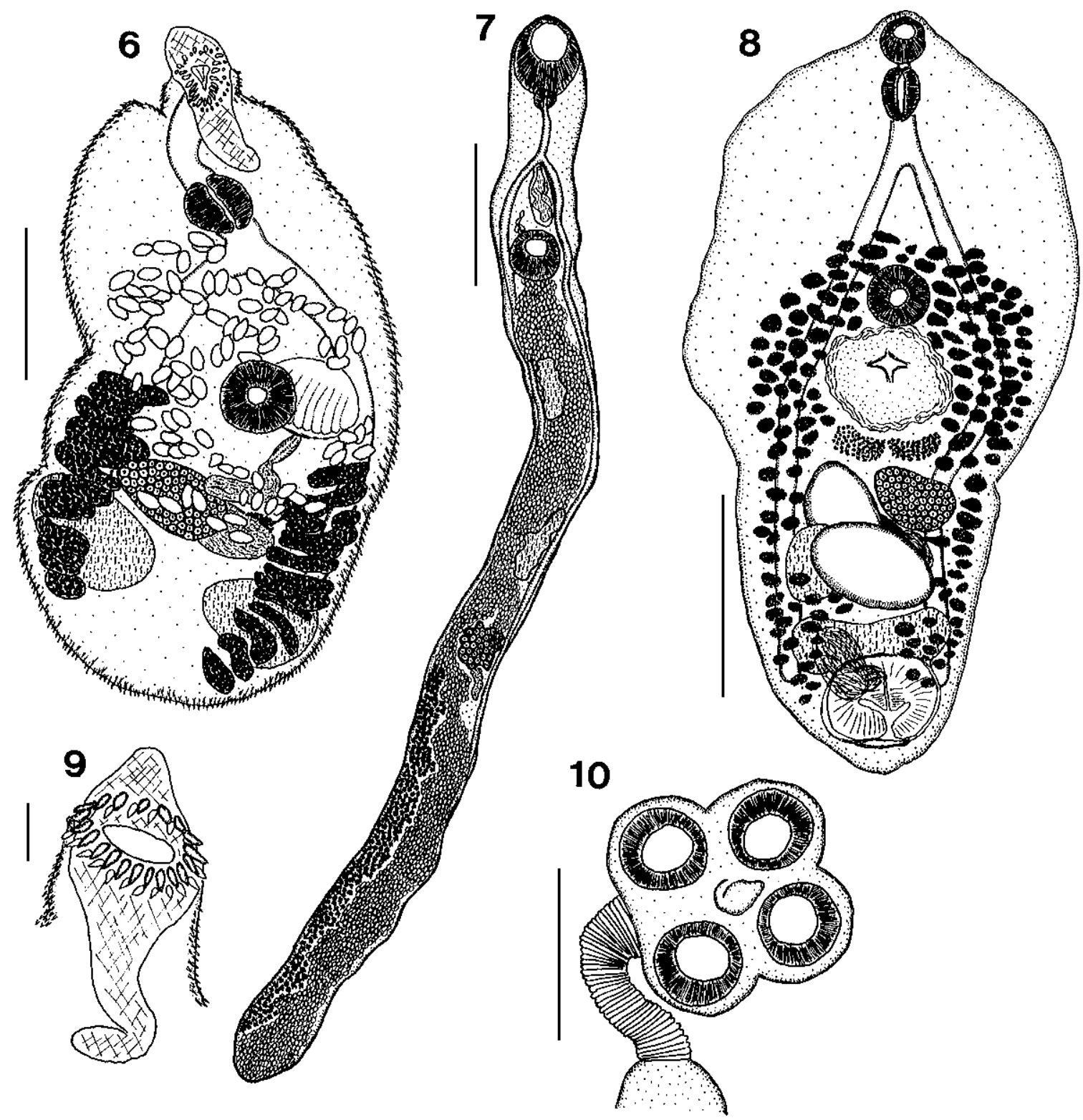

Figs. 6-10. Digeneans and cestodes parasitic in Plegadis chihi. Fig. 6. Ascocotyle (Leighia) hadra, ventral view. Fig. 7. Athesmia heterolecithodes, ventral view. Fig. 8. Posthodiplostomum nanum, ventral view. Fig. 9. Ascocotyle (L.) hadra, detail of anterior extremity. Fig. 10. Hymenolepis megalops, scolex. Scale bars: Figs. $6,8=0.1 \mathrm{~mm}$; Fig. $7=0.5 \mathrm{~mm}$; Fig. $9=0.02 \mathrm{~mm}$; Fig. $10=$ $1 \mathrm{~mm}$.

- Ascocotyle (Phagicola) angrense Travassos, 1916 from naturally infected Ixobrychus involucris (Ostrowski de Núñez 1974, 1993). This species was also reported as Phagicola angrensis Travassos, 1916 from Ajaia ajaja (=Platalea ajaja) (Boero and Led 1970) and Casmerodius albus egretta (=Egretta alba) (Boero et al. 1972b), from the La Plata Zoological Garden.
- Ascocotyle (P.) diminuta (Stunkard et Haviland, 1924), obtained experimentally in chicks and mice and also found in Egretta thula (Ostrowski de Núñez 1993).

- A. (P.) angeloi Travassos, 1928, obtained experimentally in chicks and mice by Ostrowski de Núñez (1998). 
Table 3. Comparative measurements of Ascocotyle (Leighia) hadra in both experimental and natural hosts.

\begin{tabular}{|lc|c|c|}
\hline & & $\begin{array}{c}\text { Experimental Gallus gallus f. dom. } \\
\text { (Ostrowski de Núñez 1992) }\end{array}$ & $\begin{array}{c}\text { Plegadis chihi } \\
\text { (Present study) }\end{array}$ \\
\hline $\mathrm{N}$ & 20 & 20 \\
Body length & & $0.496-0.798(0.614)$ & $0.394-0.671(0.507)$ \\
Body width & $0.260-0.353(0.289)$ & $0.184-0.259(0.221)$ \\
Oral sucker (+ projection) & length & $0.084-0.162(0.119)$ & $0.054-0.130(0.097)$ \\
& width & $0.046-0.067(0.056)$ & $0.030-0.056(0.041)$ \\
Pharynx & length & $0.036-0.063(0.050)$ & $0.041-0.060(0.047)$ \\
& width & $0.032-0.053(0.040)$ & $0.031-0.053(0.041)$ \\
Ventral sucker & length & $0.042-0.069(0.054)$ & $0.040-0.055(0.046)$ \\
Ventral sucker to anterior & endidth & $0.046-0.074(0.057)$ & $0.040-0.058(0.048)$ \\
Ovary & length & $0.235-0.428(0.316)$ & $0.187-0.397(0.277)$ \\
& width & $0.053-0.084(0.062)$ & $0.029-0.060(0.044)$ \\
Right testis & length & $0.053-0.095(0.074)$ & $0.036-0.094(0.060)$ \\
Left testis & width & $0.063-0.088(0.071)$ & $0.039-0.096(0.057)$ \\
& length & $0.084-0.147(0.105)$ & $0.046-0.120(0.075)$ \\
Eggs & width & $0.053-0.095(0.072)$ & $0.037-0.084(0.056)$ \\
Spines of oral sucker & anterior row & $0.074-0.137(0.108)$ & $0.044-0.110(0.073)$ \\
& posterior row & $19-23 \times 12.6-16.8 \mu \mathrm{m}$ & $18.4-22.3 \times 10.6-12.6 \mu \mathrm{m}$ \\
Tegumental spines & & $18-21(11-13 \mu \mathrm{m})$ & $18-23(10.6-12.6 \mu \mathrm{m})$ \\
No. of folds of gonotyl & & $5.8-6.7 \mu \mathrm{m}$ & $18-23(6.7-9.7 \mu \mathrm{m})$ \\
\hline
\end{tabular}

Athesmia heterolecithodes (Braun, 1899) Looss, 1899 Fig. 7

S i t e of in fecti on: Bile ducts, gall bladder.

L o c a 1 i t i e s: Punta Blanca and Guaminí, province of Buenos Aires, Argentina.

Prevale n c e: $8.8 \%$.

In te n s it y of i n f e tion: 6-12 (mean=8.2) per infected host.

M a t e ri a 1 s t udi e d : 42 whole-mounts, 11 measured.

Comments: New host record. Athesmia heterolecithodes is a ubiquitous, nearly cosmopolitan species, originally described from birds from the Old World (Freitas 1962). The host range includes bird species of the Gruiformes, Charadriiformes, Cuculiformes, Falconiformes, Strigiformes, Ciconiiformes and Passeriformes from the Old World, Nearctic and Neotropical regions; and mammals of the Marsupialia, Chiroptera, Carnivora and Rodentia (Freitas 1962, Martínez and Binda 1992).

Earlier reports of Athesmia species in Argentina referred to mammalian hosts: Athesmia foxi Goldberger et Crane, 1911 from Pseudalopex gymnocercus (=Lycalopex gymnocercus) (Canidae) (Martínez 1985) and $A$. heterolecithodes from Myocastor coypus (Myocastoridae) (Martínez and Binda 1992). In the study area, other avian hosts observed for this species were: Aramides ypecaha (Aramidae), Vanellus chilensis (Charadriidae), Jacana j. jacana (Jacanidae) (Digiani 1999a) and Nothura maculosa (Tinamidae) (C. Mordeglia, affiliation as above; pers. comm.).

\section{Posthodiplostomum nanum Dubois, 1937}

Fig. 8, Table 4

S i te of infection: Intestine.

L o c a 1 i t y : Punta Blanca, province of Buenos Aires, Argentina.

Prevale n c e : $29 \%$.

Intensity of infection: 1-11,240 (mean=878.3) per infected host.

M a t e ri a 1 s t u di e d: 54 whole-mounts, 17 measured.

Comments: New host record. This species was originally described from Butorides virescens (Ardeidae) from Cuba and Brazil and reported from Argentina by Boero et al. (1972b) and Ostrowski de Núñez (1973). The extremely small size of these specimens approximates them to $P$. nanum Dubois, 1937, the smallest species in the genus. They also resemble $P$. nanum in the arrangement of gonads and vitelline follicles. However, they differ from the description of $P$. nanum by Dubois (1970) in their smaller size, the longitudinal instead transversal opening of the tribocytic organ and the forebody, which is never wider than long. The dimensions of the present specimens are closer to those Boero et al. (1972b) allocated to $P$. nanum from Casmerodius albus egretta (=Egretta alba), though their description is rather incomplete, giving dimensions of the body and suckers, and illustrating the forebody wider than long.

Much experimental work has been conducted to document the wide degree of morphological hostinduced variation in Posthodiplostomum species 
Table 4. Comparative measurements of Posthodiplostomum nanum (in $\mu \mathrm{m}$ ).

\begin{tabular}{|c|c|c|c|c|c|}
\hline & & Dubois (1970) & Boero and Led (1972) & $\begin{array}{c}\text { Ostrowski de Núñez } \\
\text { (1973) }\end{array}$ & Present study \\
\hline \multicolumn{2}{|l|}{$\begin{array}{c}\mathrm{N} \\
\text { Host }\end{array}$} & $\begin{array}{c}\text { not given } \\
\text { Butorides virescens }\end{array}$ & $\begin{array}{c}\text { not given } \\
\text { Casmerodius albus }\end{array}$ & $\begin{array}{c}3 \\
\text { Ducks (experimental) }\end{array}$ & $\begin{array}{c}17 \\
\text { Plegadis chihi }\end{array}$ \\
\hline \multicolumn{2}{|l|}{ Total body length } & "up to $950 "$ & $420-600$ & $551-636$ & $396-483(436)$ \\
\hline Forebody & $\begin{array}{l}\text { length } \\
\text { width }\end{array}$ & $\begin{array}{l}250-540 \\
140-160\end{array}$ & not given & $\begin{array}{l}391-477 \\
233-254\end{array}$ & $\begin{array}{l}237-333(279) \\
159-222(189)\end{array}$ \\
\hline Hindbody & $\begin{array}{l}\text { length } \\
\text { width }\end{array}$ & $\begin{array}{c}160-410 \\
90-380\end{array}$ & not given & $\begin{array}{l}190-243 \\
148-159\end{array}$ & $\begin{array}{l}116-193(157) \\
097-179(142)\end{array}$ \\
\hline \multicolumn{2}{|c|}{ Ratio Hind/Forebody } & $0.55-0.79$ & not given & not given & $0.40-0.78$ \\
\hline Oral sucker & $\begin{array}{l}\text { length } \\
\text { width }\end{array}$ & $\begin{array}{l}26-60 \\
24-47\end{array}$ & $25-30 \varnothing$ & $\begin{array}{c}37-40 \\
32-27 \text { (sic) }\end{array}$ & $\begin{array}{l}24-39(27) \\
19-34(25)\end{array}$ \\
\hline Prepharynx & & "short" & not given & not given & $7-29$ \\
\hline Pharynx & $\begin{array}{l}\text { length } \\
\text { width }\end{array}$ & $\begin{array}{l}24-54 \\
18-46\end{array}$ & not given & $\begin{array}{l}27-29 \\
21-27\end{array}$ & $\begin{array}{l}26-31(27) \\
14-31(18)\end{array}$ \\
\hline Ventral sucker & $\begin{array}{l}\text { length } \\
\text { width }\end{array}$ & $\begin{array}{l}24-46 \\
30-60\end{array}$ & $40 \varnothing$ & $\begin{array}{l}40-43 \\
45-54\end{array}$ & $29-36(32) \varnothing$ \\
\hline Tribocytic organ & $\begin{array}{l}\text { length } \\
\text { width }\end{array}$ & $\begin{array}{l}43-76 \\
60-96\end{array}$ & not given & $\begin{array}{c}67-94 \\
72-116\end{array}$ & $55-70(60) \varnothing$ \\
\hline Anterior testis & $\begin{array}{l}\text { length } \\
\text { width }\end{array}$ & $\begin{array}{l}45-145 \\
55-165\end{array}$ & not given & $\begin{array}{l}62-64 \\
78-91\end{array}$ & $\begin{array}{l}31-53(40) \\
53-133(99)\end{array}$ \\
\hline Posterior testis & $\begin{array}{l}\text { length } \\
\text { width }\end{array}$ & $\begin{array}{c}55-175 \\
082-186\end{array}$ & not given & $\begin{array}{c}43-54 \\
116-148\end{array}$ & $\begin{array}{l}27-43(34) \\
51-120(89)\end{array}$ \\
\hline $\begin{array}{l}\text { Ovary } \\
\text { Eggs }\end{array}$ & $\begin{array}{l}\text { length } \\
\text { width }\end{array}$ & $\begin{array}{c}24-73 \\
29-120 \\
62-76 \times 42-48\end{array}$ & $\begin{array}{c}\text { not given } \\
\text { not present }\end{array}$ & $\begin{array}{c}27-48 \\
40-54 \\
89 \times 48\end{array}$ & $\begin{array}{c}24-48(36) \\
48-67(54) \\
75-87 \times 43-55\end{array}$ \\
\hline
\end{tabular}

(Campbell 1972, Palmieri 1976, 1977a, 1977b, 1977c, Pérez Ponce de León 1995), which demonstrated the lack of host specificity in the genus. Specimens encountered here, though slightly smaller, also resemble the adults of a Posthodiplostomum species, attributed to $P$. nanum, obtained experimentally in ducks by Ostrowski de Núñez (1973: fig. 14) from naturally obtained metacercariae. The experimental adults from chicks and ducklings differed in the forebody length/width ratio both from the original description of $P$. nanum and from specimens found in naturally infected Butorides striatus and Ixobrychus involucris from the same area, the differences being attributed to host-induced variation (Ostrowski de Núñez 1973). Taking this into account, specimens obtained from $P$. chihi were provisionally allocated to $P$. nanum, which represented the morphologically closest species. This would be supported by the fact that metacercariae identical to those described by Ostrowski de Núñez (1973) were found in the same fish host (C. decenmaculatus) in the area where most of the birds were observed to feed.

Nearly all hosts of Posthodiplostomum spp. belong to the family Ardeidae. Previous reports from other avian hosts are P. minimum in Eudocimus albus, Platalea ajaja (Threskiornithidae) and Cassidix mesomexicanus (Icteridae) (Bush and Forrester 1976, Sepúlveda et al. 1994, Lumsden and Zischke 1963, respectively) and $P$. mehtai (sic) in Milvus migrans (Accipitridae) (Gupta and Mishra 1974). Reports of Posthodiplostomum spp. from Argentinean birds are those of P. nanum by Boero et al. (1972b), Ostrowski de Núñez (1973), and that of P. mignum by Boero et al. (1972b) from Ardea cocoi.

\section{Cestoda}

Hymenolepis megalops (Nitzch in Creplin, 1829) (=Cloacotaenia megalops Wolffhügel, 1938) Fig. 10

Site of infection: Cloaca.

L o c a 1 i t y : Punta Blanca, province of Buenos Aires, Argentina.

Prevale n c e: $10.7 \%$.

Inten sity of infection: 1-2 per infected host.

Material studied: 3 fragmented specimens.

Comments: New host record. The generic allocation of the species follows Czaplinsky and Vaucher (1994). The specimens, most gravid, were always severely macerated, which made accurate measurements impossible. However, the characteristic size and shape of the scolex, as well as the cloacal site of infection, made the identification of this cestode possible. It was previously reported from Argentina (as Cloacotaenia megalops) from the cloaca of Querquedula cyanoptera, $Q$. versicolor, Dendrocygna viduata and Poecilonetta spinicauda (Anatidae) (Boero et al. 1972a). Other hosts recorded for this species are Anas bahamensis rubrirostris from Saladillo, Anas sp. from Punta Blanca, Netta peposaca from General Belgrano and Cygnus 
melancorypha from Chascomús, all from Buenos Aires province (unpublished data). These host records, together with previous reports, summarised by MunizPereira and Amato (1998) clearly show that Anseriformes (Anserinae and Anatinae) are preferential hosts of $H$. megalops, with few reports from Galliformes and Gruiformes (Muniz-Pereira and Amato 1998). Plegadis chihi becomes the first ciconiiform host known for $H$. megalops.
Acknowledgements. Dr. Margarita Ostrowski de Núñez, who co-guided the author's PhD. studies, is gratefully acknowledged. The author is also indebted to Dr. Helmut Sattmann, curator of the helminthological collection of the Naturhistorisches Museum, Vienna, Austria, who provided type material, and to the staff of the Cátedra de Ornitología, Facultad de Ciencias Naturales y Museo, Universidad Nacional de La Plata, for providing the hosts studied. This study was carried out while the author had a fellowship from the Consejo Nacional de Investigaciones Científicas y Técnicas (CONICET), Argentina.

\section{REFERENCES}

BOERO J.J., LED J.E. 1968: El parasitismo de la fauna autóctona. III. Los parásitos de las aves argentinas. Rev. Fac. Cienc. Vet. La Plata 10: 97-129.

BOERO J.J., LED J.E. 1970: El parasitismo de la fauna autóctona VI. Los parásitos de la avifauna argentina (1). $5^{\circ}$ Jornadas de Veterinaria, pp. 65-71.

BOERO J.J., LED J.E. 1971: El parasitismo de la fauna autóctona. v) Los parásitos de las aves argentinas. vi) Los parásitos de los ofidios argentinos. vii) Los parásitos de los murciélagos argentinos. Analecta Vet. 3: 91-103.

BOERO J.J., LED J.E., BRANDETTI E. 1972a: Algunos parásitos de la avifauna argentina. Analecta Vet. 4: 17-34.

BOERO J.J., LED J.E., BRANDETTI E. 1972b: El parasitismo de la fauna autóctona. Rev. Agron. Vet. 1: 17-29.

BUSH A.O., FORRESTER D.J. 1976: Helminths of the White Ibis in Florida. Proc. Helminthol. Soc. Wash. 43: 17-23.

CAMPBELL R.A. 1972: New experimental hosts for Posthodiplostomum minimum. J. Parasitol. 58: 1051.

CZAPLINSKY B., VAUCHER C. 1994: Family Hymenolepididae. In: L.F. Khalil, A. Jones and R.A. Bray (Eds.), Key to the Cestode Parasites of Vertebrates. CAB International, Wallingford, pp. 595-663.

DIETZ E. 1909: Die Echinostomiden der Vögel. PhD. Dissertation, University of Königsberg, $37 \mathrm{pp}$.

DIETZ E. 1910: Die Echinostomiden der Vögel. Zool. Jahrb. Suppl. 12: 268-493.

DIGIANI M.C. 1999a: Estudios helmintológicos en aves limnícolas del litoral rioplatense. Tesis Doctoral, Facultad de Ciencias Naturales y Museo, Universidad Nacional de La Plata, 148 pp.

DIGIANI M.C. 1999b: First record of the genus Syncuaria (Nematoda: Acuariidae) in Argentina, with description of a new species. Folia Parasitol. 46: 139-144.

DIGIANI M.C. 2000: Tetrameres (Gynaecophila) aspicula n. sp. (Nematoda: Tetrameridae), a proventricular parasite of the white-faced ibis Plegadis chihi in Argentina. Syst. Parasitol. 47: 111-117.

DUBOIS G. 1970: Synopsis des Strigeidae et des Diplostomatidae (Trematoda). Mém. Soc. Neuchâtel Sci. Nat. 10: 259-727.

FREITAS J.F.T. 1962: Notas sôbre o gênero Athesmia Looss, 1899. Arq. Mus. Nac. Rio de J. 52: 85-104.

GUPTA N.K., MISHRA P.N. 1974: On a new trematode, Posthodiplostomum mehtai (Family Diplostomatidae) from Milvus migrans at Simla (Himachal). Indian J. Helminthol. 2: 23-27.
HUFFMAN J.E., FRIED B. 1990: Echinostoma and Echinostomiasis. Adv. Parasitol. 29: 215-269.

JAIN S.P., SRIVASTAVA O.N. 1970: On the validity of some species of the genus Patagifer (Trematoda: Echinostomatidae). Proc. Indian Acad. Sci. Sec. B 72: 156-161.

KANEV I. 1985: On the morphology, biology, ecology and taxonomy of E. revolutum group (Trematoda: Echinostomatidae: Echinostoma). Ph.D. Dissertation, University of Sofia, Bulgaria, 64 pp. (In Bulgarian.)

KANEV I. 1994: Life-cycle, delimitation and redescription of Echinostoma revolutum (Froelich, 1802) (Trematoda: Echinostomatidae). Syst. Parasitol. 28: 125-144.

KOHN A., FERNANDES B.M.M. 1972: Sobre a validade das espécies pertenecentes ao género Prosthogonimus Luehe, 1899, da coleçao helmintológica do Instituto Oswaldo Cruz. Mem. Inst. Oswaldo Cruz 70: 309-325.

LUMSDEN R.D. 1962: Four echinostome trematodes from Louisiana birds including the description of a new species. Tulane Stud. Zool. 9: 301-308.

LUMSDEN R.D., ZISCHKE J.A 1963: Studies on the trematodes of Louisiana birds. Z. Parasitenkd. 22: 316366.

MARTÍNEZ F.A. 1985: Athesmia foxi Goldberger y Crane, 1911 (Trematoda: Dicrocoeliidae) en Pseudalopex gymnocercus de Argentina. Vet. Argent. 2: 875-878.

MARTÍNEZ F.A., BINDA J.L. 1992: Athesmia heterolecithodes (Braun, 1899) Looss, 1899 (Trematoda: Dicrocoeliidae) en Myocastor coypus. Vet. Argent. 9: 98101.

MATHEU A., del HOYO J. 1992: Family Threskiornithidae. In: J. del Hoyo, A. Elliott and J. Sargatal (Eds.), Handbook of the Birds of the World. Vol. 1. Lynx Edicions, Barcelona, pp. 472-506.

MUNIZ-PEREIRA L.C., AMATO S.B. 1998: Fimbriaria fasciolaris and Cloacotaenia megalops (Eucestoda, Hymenolepididae), cestodes from Brazilian waterfowl. Mem. Inst. Oswaldo Cruz 93: 767-772.

NAVAS J.R. 1995: Ciconiiformes: Threskiornithidae y Phoenicopteridae. Fauna de agua dulce de la República Argentina 43: 1-53.

ONDA C., IMAI S., ISHII T. 1983: A new echinostome trematode, Patagifer toki sp. n., from the Japanese Crested Ibis, Nipponia nippon. Jpn. J. Parasitol. 32: 177-182. 
OSTROWSKI de NÚÑEZ M. 1973: Sobre el ciclo biológico experimental de Posthodiplostomum nanum Dubois, 1937 (Trematoda, Diplostomatidae). Physis 32: 121-132.

OSTROWSKI de NÚÑEZ M. 1974: Estudio sobre estadios larvales de Trematodes Digeneos de peces Cyprinodontiformes. Physis Sec. B 33: 45-61.

OSTROWSKI de NÚÑEZ M. 1976: Fauna de agua dulce en la República Argentina. IV. Las cercarias de Ascocotyle (A.) tenuicollis Price 1935 y de Pygidiopsis pindoramensis Travassos 1929 (Trematoda, Heterophyidae). Physis Sec. B 35: 51-57.

OSTROWSKI de NÚÑEZ M. 1992: Life history studies of heterophyid trematodes in the Neotropical Region: Ascocotyle (Leighia) hadra n. sp. Mem. Inst. Oswaldo Cruz 87: 539-543.

OSTROWSKI de NÚÑEZ M. 1993: Life history studies of heterophyid trematodes in the Neotropical Region: Ascocotyle (Phagicola) diminuta (Stunkard \& Haviland, 1924) and A. (P.) angrense Travassos, 1916. Syst. Parasitol. 24: 191-199.

OSTROWSKI de NÚÑEZ M. 1998: Life history of Ascocotyle (Phagicola) angeloi (Digenea: Heterophyidae) in the Neotropical Region. Folia Parasitol. 45: 199-204.

PALMIERI J. 1976: Host parasite relationships and intraspecific variation in Posthodiplostomum minimum (Trematoda: Diplostomatidae). Great Basin Naturalist 36: 334-346.

PALMIERI J. 1977a: Host-induced morphological variations in the strigeoid trematode Posthodiplostomum minimum (Trematoda: Diplostomatidae) II: body measurements and tegument modifications. Great Basin Nat. 37: 129-137.

PALMIERI J. 1977b: Host-induced morphological variations in the strigeoid trematode Posthodiplostomum minimum

Received 23 November 1999
(Trematoda: Diplostomatidae) III: organs of attachment. Great Basin Nat. 37: 375-382.

PALMIERI J. 1977c: Host-induced morphological variations in the strigeoid trematode Posthodiplostomum minimum (Trematoda: Diplostomatidae) IV: organs of reproduction (ovary and testes), vitelline gland and egg. Great Basin Nat. 37: 475-482.

PÉREZ-PONCE de LEÓN G. 1995: Host-induced morphological variability in adult Posthodiplostomum minimum (Digenea: Neodiplostomidae). J. Parasitol. 81: 818-820.

RICHARD J. 1964: Trématodes d' Oiseaux de Madagascar (Note III). Espèces de la famille Echinostomatidae Poche, 1926. Ann. Parasitol. Hum. Comp. 39: 607-620.

SEPÚLVEDA M.S., SPALDING M.G., KINSELLA J.M., BJORK R.D., McLAUGHLIN G.S. 1994: Helminths of the Roseate Spoonbill, Ajaia ajaja, in Southern Florida. J. Helminthol. Soc. Wash. 61: 179-189.

THATCHER V.E. 1993: Trematódeos Neotropicais. Instituto Nacional de Pesquisas da Amazônia, Manaus, Brazil, 553 pp.

TRAVASSOS L. 1922: Informaçoes sôbre a fauna helmintológica de Mato Grosso. Fôlha Méd. 3: 187-190.

TRAVASSOS L. 1928: Fauna helmintológica de Mato Grosso. Mem. Inst. Oswaldo Cruz 21: 309-341.

TRAVASSOS L., FREITAS J.F.T., KOHN A. 1969: Trematódeos do Brasil. Mem. Inst. Oswaldo Cruz 67: $1-886$.

WOLFFHÜGEL K. 1909: Trematodes (Fasciola hepatica L. y Prosthogonimus cuneatus (Rudolphi) parásitos de los animales domésticos de la República Argentina. Rev. Cent. Estud. Agron. Vet. 1: 5-8.

YAMAGUTI S. 1971: The Digenetic Trematodes of Vertebrates. Keigaku Publishing Co., Tokyo, 1071 pp.

Accepted 31 March 2000 